\title{
Reproductive biology of the flatfish Etropus crossotus (Pleuronectiformes: Paralichthyidae) in the Paranaguá Estuarine Complex, Paraná State, subtropical region of Brazil
}

\author{
Elton Celton de Oliveira ${ }^{1,2}$ and Luís Fernando Favaro ${ }^{2,3}$
}

The present work studied the reproduction of the flatfish Etropus crossotus in the Paranaguá Estuarine Complex, Paraná State, subtropical region of Brazil. Monthly collections of biological material occurred from October 2008 to October 2009, at seven sampling sites, through ten-minute otter trawl surveys in the shallow infralittoral areas of the estuary. Temperature, water salinity, photoperiod, and rainfall data were also recorded. Ovarian histology was used to: 1 - describe ovarian development microscopically, 2 - make the quantitative analyses of both sexes more precise. The maturation curve, the frequency of gonadal maturation states and the condition factor verified that the reproductive period occurred from October to January. The frequency of young and adult individuals established that the recruitment period occurred in January and February. There were no significant differences in the sex ratio during the study period. The studied species completes its entire life cycle in an estuary and its reproduction is well-synchronized with the temporal variations implicit in subtropical regions.

O presente trabalho estudou a reprodução do linguado Etropus crossotus no complexo estuarino de Paranaguá, região subtropical do Brasil. Coletas mensais de material biológico ocorreram de outubro de 2008 a outubro de 2009, em sete pontos amostrais, através da realização de dez minutos de arrasto de porta no infralitoral raso do estuário. Ainda, foram obtidos dados de temperatura e salinidade da água, fotoperíodo e pluviosidade para caracterização do ambiente. A histologia de ovário foi utilizada para: 1- descrever microscopicamente o desenvolvimento ovariano, 2- conferir precisão aos resultados das análises quantitativas de ambos os sexos. Através da curva de maturação, da frequência de estádios de maturação gonadal e do fator de condição verificou-se que o período reprodutivo ocorreu de outubro a janeiro. A partir da frequência de indivíduos jovens e adultos constatou-se que o período de recrutamento ocorreu em janeiro e fevereiro. Não se obteve diferenças significativas na proporção sexual ao longo do período estudado. A espécie estudada completa todo o seu ciclo de vida em estuários e sua reprodução mostrou-se bem sincronizado às variações temporais implícitas em regiões subtropicais.

Key words: First maturation length, Partially spawned, Recruitment, Reproductive period.

\section{Introduction}

Studies of the reproductive process help support the inferences made about the biology of analyzed species and their relation to the environment, making possible the evaluation of stocks, the regulation of the fishery and the implementation of management plans when necessary (Fávaro $\&$ Oliveira, 2011).

This process is responsible for the viability of fish populations and is synchronized with environmental variations. According to Jobling (1995) and Shiota \& Soyano
(2003), the mechanisms that furnish the initial physiological "trigger" of the fish reproductive process, in temperate and subtropical regions, are related to seasonal variations in photoperiod and temperature.

The fish species known popularly as flatfishes are considered a very specialized monophyletic group (Berendzen \& Dimmick, 2002), with very uncommon morphological characteristics (Mendonça \& Araujo, 2002). Their representatives belong to the order Pleuronectiformes, which consists of 570 species, 123 genera and 11 families (Nelson, 2006), and are widely distributed geographically, occurring

${ }^{1}$ Universidade Tecnológica Federal do Paraná (UTFPR), campus Campo Mourão, BR 369, km 0,5, Caixa Postal: 271, 87301-006 Campo Mourão, PR, Brazil. eltonoliveira@utfpr.edu.br

${ }^{2}$ Universidade Federal do Paraná (UFPR), Laboratório de Reprodução e Comunidade de Peixes, Caixa Postal: 19031, 81531-990, Curitiba, PR, Brazil.

${ }^{3}$ Universidade Federal do Paraná (UFPR), Departamento de Biologia Celular, Setor de Ciências Biológicas, Caixa Postal: 19031, 81531-990 Curitiba, PR, Brazil. lufavaro@ufpr.br (corresponding author) 
from arctic and subantarctic regions (Bailey et al., 2008) to tropical and subtropical environments (Guedes \& Araujo, 2008), where they correspond to three fourths of all recorded flatfishes (Pardo et al., 2005).

In Brazil, the flatfishes are widely distributed along the coast and are found in large numbers in estuarine and marine environments, although they also occur in freshwater regions (Figueiredo \& Menezes, 2000). Some species of Brazilian coastal flatfishes have added to the knowledge about reproductive biology (Chaves \& Vendel, 1997; Dias et al., 2005; Oliveira \& Fávaro, 2010), food ecology (Chaves \& Serenato, 1998; Lunardon-Branco \& Branco, 2003; Guedes et al., 2004; Guedes \& Araujo, 2008) and population composition. Even so, little is known about the autoecological parameters of most of the species that occur in Brazil.

The species Etropus crossotus Jordan \& Gilbert, 1882, object of this study, belongs to the family Paralichthyidae, with the flatfish as the most frequent and abundant of the Paranaguá Estuarine Complex, Paraná, Brazil (Queiroz et al., 2006; Felix et al., 2007), study area of the present work. It is a small-sized species (up to $17 \mathrm{~cm}$ in total length) that frequently occurs in shallow estuarine areas with a sandy substrate (Figueiredo \& Menezes, 2000), feeds on, mainly, crustaceans, polychaetes and small-sized fishes (Lunardon-Branco \& Branco, 2003) and is thus ecologically important in the maintenance of the trophic chain.

Etropus crossotus presents wide geographic distribution along the Atlantic, occurring from Chesapeake Bay (USA) to southern Brazil (Rio Grande do Sul) (Figueiredo \& Menezes, 2000). This characteristic shows the adaptability of the species to the different climatic conditions imposed by the tropical, subtropical and temperate regions. Thus, the knowledge produced about the reproductive activity of this species becomes important as regards its population dynamics related to environmental variations.

In addition, due to a lack of information about the reproductive biology of the flatfish E. crossotus, the study of the reproduction of this species increases the knowledge of its autoecological parameters and verifies the use that the species makes of a subtropical estuarine environment, which presents in its surroundings, the occurrence of different types and intensities of anthropogenic actions (Andriguetto-Filho et al., 2006).

The present work had the following objectives: ascertain the periods of reproduction and recruitment, ascertain the type of spawning, make inferences about the type of growth, estimate the condition (wellbeing) of the individuals and verify the sexual ratio and the ratio of young and adult individuals of E. crossotus of the Paranaguá Estuarine Complex.

\section{Material and Methods}

\section{Study area}

The Paranaguá Estuarine Complex (Fig. 1) is located in the northern part of the coastal plain of the State of Paraná, subtropical region of Brazil $\left(25^{\circ} 15^{\prime}\right.$ to $25^{\circ} 35^{\prime} \mathrm{S}$ and $48^{\circ} 10^{\prime}$ to $\left.48^{\circ} 45^{\prime} \mathrm{W}\right)$, and is composed of five main bodies of water (Antonina, Paranaguá, Laranjeiras, Guaraqueçaba, and Pinheiros bays) (Lana et al., 2001). On the north-south axis of this estuary, the predominant sedimentological composition is composed of fine sand and very fine sand (Lamour et al., 2004; Lamour, 2007).

This estuarine system is located near urban centers, while the surrounding areas include ports, agriculture and pastures (Ipardes, 2001). Artisanal fishing, carried out by the local community, occurs in the interior of the system, while industrial fishing occurs in the adjacent sea, and is carried out by vessels from other states (Andriguetto-Filho et al., 2006). Waste from different industries has reached its waters, in addition to the intense traffic of ships from different ports that access the ports of Antonina and Paranaguá.

According to the Köppen classification, the climate of the region is subtropical humid mesothermal (Cfa). The air temperature in the hottest month presents an average above $22^{\circ} \mathrm{C}$, while in the coldest month it presents an average below $18^{\circ} \mathrm{C}$. The average humidity of the region is $85 \%$, with an average annual precipitation of $2500 \mathrm{~mm}$ (Lana et al., 2001).

\section{Sampling procedure}

The collections of biological material and environmental data used in this study occurred monthly from October 2008 to October 2009 at seven sampling sites along the north-south axis of the Paranaguá Estuarine Complex (Paraná state) (Fig. 1). The specimens of E. crossotus were collected in the shallow infralittoral areas (3.0 to $6.0 \mathrm{~m}$ deep), in sandy substrate, through 10-minute otter trawl surveys at each sampling site.

Water was collected at the same depth as the above surveys using a Van Dorn bottle. Water temperature and water salinity data, measured using a mercury thermometer and a refractometer, respectively, were recorded together with rainfall and photoperiod data of the municipality of Paranaguá

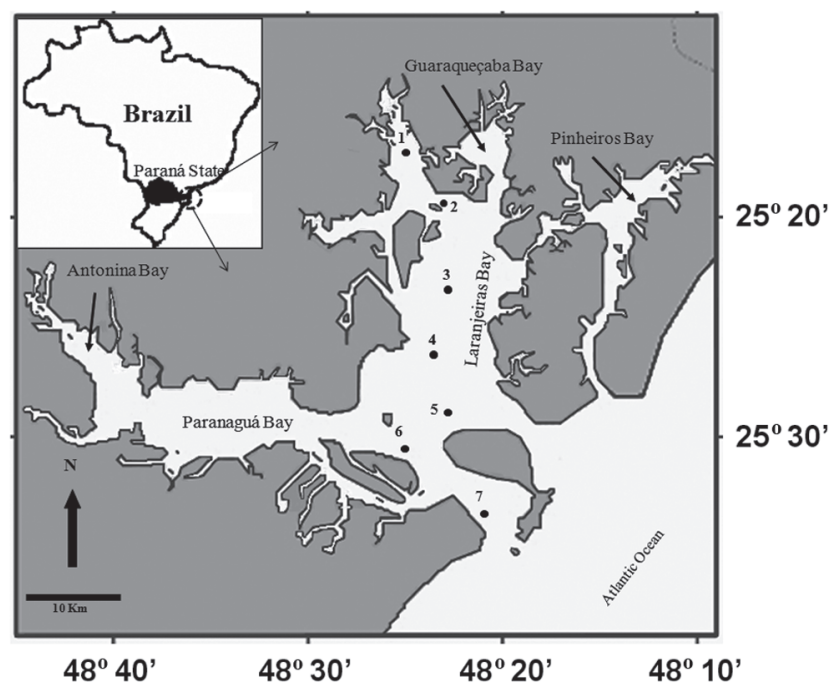

Fig. 1. Location of the sampling sites in the Paranaguá Estuarine Complex, Paraná State, subtropical region of Brazil. 
(Paraná state). The data of the former were furnished by Instituto Nacional de Meteorologia (INMET) and the data of the latter were supplied by Instituto Tecnológico - Sistema Meteorológico do Paraná (SIMEPAR).

The specimens were identified in the laboratory (Figueiredo \& Menezes, 2000); later the following measurements were taken: total length $(\mathrm{Lt})$, in centimeters, and total weight (Wt), in grams.

After lateral section the individuals had their gonads exposed. They were analyzed macroscopically as regards sex and gonadal development, according to the ovarian maturity scale proposed by Vazzoler (1996) and the testicular maturity scale proposed by Gomes \& Araujo (2004). The gonads were removed, weighed (Wg) and some fixed in ALFAC for 20 hours. They were routinely processed (Fávaro \& Oliveira, 2011) to make histological slides, which were stained with hematoxylin-eosin (HE) for microscopic analysis. Light microscopy was used to confirm the gonadal development stages, wich were determined macroscopically.

The specimens of $E$. crossotus collected for the present work were deposited in the fish collection of Museu de História Natural do Capão da Imbuia (MHNCI), Curitiba (Paraná State) (Etropus crossotus: MHNCI 3009).

\section{Data analysis}

The water temperature, water salinity, photoperiod and rainfall data obtained during the study period were used to characterize the temporal variation in the abiotic factors in the studied environment. The Pearson correlation was used to verify the relationship between the measured environmental variables.

The histological evaluation of the testicles was performed according to Gomes \& Araújo (2004); however, we chose to describe only oogenesis microscopically and create a maturity scale for females, since the gonads of females are more easily characterized as regards gonadal development stages, being able to more precisely estimate the time and type of spawning, in addition to showing great temporal weight changes compared to those of males, which makes the application of the quantitative evaluators easier (West, 1990).

The oogenesis phases were determined by the comparative size of the ovarian follicles, the affinity for the dyes hematoxylin-eosin (HE), the appearance of follicular cells and the vitelline membrane, and the occurrence of cytoplasmic vesicles and yolk granules. The maturity scale was made based on the composition and the frequency of the ovarian follicle phases.

In addition to the histology, the evaluation of the reproduction of $E$. crossotus was made according to the weight-length relationship, monthly variation of the mean GSI, the percentage frequency distribution of the gonadal development stages, first maturation size, sex ratio, and ratio of young and adult individuals. These analyses tried to identify the reproductive tactics of the species, as well as determine the reproductive period, the type of spawning and the recruitment period.
The weight-length relationship was estimated according to the potential model:

$\mathrm{Wt}=a \mathrm{Lt}^{\mathrm{b}}$, where $\boldsymbol{a}$ corresponds to the linear coefficient and $\boldsymbol{b}$ to the angular coefficient. The coefficients, linear and angular, were determined from the application of the method of the least squares. The equations of the weight-length relationship, estimated for grouped and separated sexes, were compared using the confidence interval method (Takeuti et al., 1999; Vitule et al., 2008).

The monthly mean GSI, used for separated sexes, was estimated using the Gonadosomatic Index (GSI) of each individual, calculated by the formula: $\mathrm{GSI}=(\mathrm{Wg} /$ $\mathrm{Wt}) * 100$, where $\mathrm{Wg}=$ weight of the gonads and $\mathrm{Wt}=$ total weight of the individual.

After the determination of the gonadal development stages, confirmed histologically, a monthly percentage frequency distribution of the development stages for separated sexes was carried out.

In order to link resource allocation to the reproductive process, the mean of the total condition factor $(\mathrm{K})$, for both sexes, and the mean of the somatic condition factor ( $\left.\mathrm{K}^{\prime}\right)$, only for females, were calculated monthly. $\mathrm{K}$ and $\mathrm{K}$ ' reflected the "wellbeing" of the individuals over the year, with the difference between them reflecting the energy used in gonadal development during the reproductive cycle. The equations used were expressed by the following formulas: $\mathrm{K}=\mathrm{Wt} / \mathrm{Lt}^{\mathrm{b}}$ and $\mathrm{K}^{\prime}=\mathrm{Wc} / \mathrm{Lt}^{\mathrm{b}}$, where $\mathrm{Wt}=$ total weight, $\mathrm{Lt}=$ total length, $\mathrm{Wc}=$ body weight $(\mathrm{Wc}=\mathrm{Wt}-\mathrm{Wg}$, where $\mathrm{Wg}=$ gonad weight), $b=$ angular coefficient obtained from the weightlength relationship.

First maturation length was established based on the shortest total length (Lt), in which $50 \%$ of the individuals sampled were adults $\left(\mathrm{L}_{50}\right) . \mathrm{L}_{50}$ was estimated, separately for males and females, through the curve that relates the relative frequency of adult individuals to the midpoint of the length classes, obtained through Sturges' Postulate (Sokal \& Rolf, 1981). The equation used to adjust the curve was expressed by the following formula: $F r=1-\left(e^{-a L t b}\right)$, where $(F r)=$ relative frequency of adult individuals, $(e)=$ neperian logarithm base, ( $a$ and b) coefficients estimated by the least squares method applied in the linear relationship obtained by the transformation of the involved variables and (Lt) midpoint of the total length classes.

The sex ratio was analyzed in two ways: monthly and in length classes (using Sturges' Postulate). The $\chi^{2}$ (Chi-square) test was applied in both cases to test differences in relation to the expected ratio of $1: 1$.

The monthly analysis of the ratio of young and adult individuals was carried out for grouped sexes. Individuals were considered young if their gonads were in the immature stage and adult if their gonads were in other stages of development. Possible monthly differences were verified in the distribution of juvenile and adult individuals through the $\chi^{2}$ test.

The Spearman correlation was used to correlate the environmental variables with the biological indices used in the reproduction studies (GSI and K) for separated sexes. 


\section{Results}

\section{Characterization of the environment}

During the present study the highest photoperiod values occurred between October and February, when the highest rainfall and lowest salinity values were also observed. Temperature presented the highest means from January to April and the lowest from June to August (Fig. 2). Using the Pearson correlation, photoperiod was positively correlated with water temperature $(r=0.54 ; \mathrm{p}<0.05)$ and rainfall $(r=$ $0.72 ; \mathrm{p}<0.05)$ and negatively correlated with salinity $(r=-$ $0.63 ; \mathrm{p}<0.05)$. Rainfall was negatively correlated with salinity $(r=-0.64 ; \mathrm{p}<0.05)$.

Oogenesis. Five ovarian follicle development phases were characterized through histological analysis (Table 1). The sixth ovarian follicle development phase or pre-ovulatory hydration, restricted to marine and estuarine fish, was not detected in this study.

Ovarian maturity scale. Five ovarian development stages were determined according to the composition and the frequency of the ovarian follicle phases (Table 2 and Fig. 3).

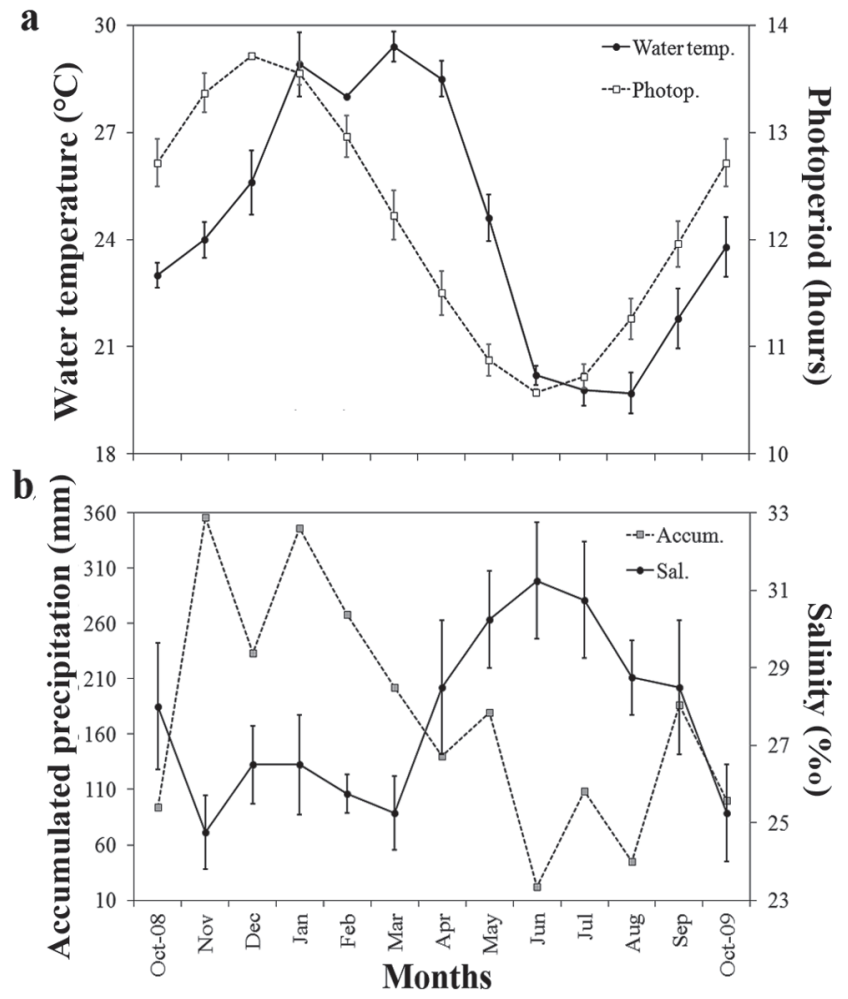

Fig. 2. Monthly distribution of the mean water temperature and photoperiod data (a), the mean accumulated precipitation and salinity (b) from October 2008 to October 2009 in the Paranaguá Estuarine Complex. Amostral $\mathrm{N}$ from water temperature $=91$, amostral $\mathrm{N}$ from, amostral $\mathrm{N}$ from photoperiod $=395$, amostral $\mathrm{N}$ from accumulated precipitation $=395$, and salinity $=91$. The error bars correspond to the standard deviation.

\section{Reproduction}

A total of 453 specimens (184 females, 237 males, and 32 unsexed individuals, represented by reduced-size specimens) were caught during the study period.

The females $(\mathrm{b}=3.18)$ and the males $(\mathrm{b}=3.15)$ of $E$. crossotus exhibited positive allometric growth and did not present differences between the angular coefficient of the growth curves. The growth for grouped sexes presented an angular coefficient (b) of 3.16 (Fig. 4).

The highest GSI mean values occurred from October to January (both sexes), with peaks in December and January for females and males, respectively (Fig. 5). Gonad weight was not recorded in January for females or in February for males due to the presence of only young specimens.

According to the distribution analysis of the monthly percentage frequency of the gonadal development stages, mature female specimens (predominance of partially spawned individuals) occurred between October and December. The predominance of immature females occurred from January to March, spawned in April and May, and maturing from June to October. As regards males, mature individuals occurred from October to January and an increase in immature specimens between December and March; emptied individuals predominated in April and May, and maturing specimens from June to October (Fig. 6). Females with partially spawned and/ or completely spawned ovaries and males with emptied testicles were obtained at every sampling site in the Paranaguá Estuarine Complex, which infers that the species uses the entire estuary in the reproductive process.

The highest mean values of $\mathrm{K}$ (both sexes) occurred in January and February and the lowest values in November and December for males and females, respectively. The greatest differences between the values of K and K' (females) occurred from October to December (highest GSI mean values) (Fig. 7).

The size of first sexual maturation $\left(\mathrm{L}_{50}\right)$ was estimated at 10.32 for females and 10.19 for males. The length at which all individuals were able to actively participate in the reproductive process $\left(\mathrm{L}_{100}\right)$ was estimated at 11.93 for females and 12.33 for males (Fig. 8). The adjustment curves of $\mathrm{L}_{50}$ were thus defined:

$F r=1-\left(e^{1.53 \times 10-19 \times \mathrm{Lt1} 18.41}\right)$, for females

$F r=1-\left(e^{6.06 \times 10-15 \times \mathrm{Lt13} 3.95}\right)$, for males

Despite the numerical predominance of males over females, no significant differences were observed over the study period $\left(\chi^{2}<3.84, p>0.05\right)$. In addition, the sex ratio per length class did not indicate significant differences, except in the class that varied from 5.8 to $6.7 \mathrm{~cm}$ (predominance of males over females) $\left(\chi^{2}=9.31, \mathrm{p}<0.05\right)$ (Fig. 9).

According to the analysis of the ratio of juveniles and adult individuals, adults predominated significantly during most of the study period $\left(\chi^{2}>3.84, \mathrm{p}<0.05\right)$. There was a significant predominance of young individuals only in January and February (recruitment period, $\chi^{2}>3.84$, $\mathrm{p}<$ 0.05) (Fig. 10).

The Spearman correlation verified that the gonadal development of females and males (GSI) of E. crossotus was more correlated with photoperiod, although rainfall and salinity 
Table 1. Microscopic description of the main morphological characteristics that determine the oogenesis phase of Etropus crossotus, obtained in the shallow infralittoral areas of the Paranaguá Estuarine Complex.

\begin{tabular}{ll}
\hline Oogenesis (phases) & Main microscopic characteristics \\
$\begin{array}{l}\text { Phase I (oogonia) } \\
\text { (Fig. 3b) }\end{array}$ & $\begin{array}{l}\text { The smallest cells of the oogenesis process generally appear grouped in "oogonial nests". They present scarce } \\
\text { cytoplasm with no affinity for dyes, a large nucleus and a single nucleolus. This phase differed from the other } \\
\text { oogenesis phases by presenting imperceptible envelope membranes when analyzed using light microscopy. The } \\
\text { other phases of the process are considered ovarian follicle development phases because they are formed by: } \\
\text { oocyte + envelope membranes, perceptible using light microscopy. }\end{array}$ \\
\hline $\begin{array}{l}\text { Phase II } \\
\text { (Fig. 3a and b) }\end{array}$ & $\begin{array}{l}\text { (cytoplasmic vesicles and vitelline granules). Follicular cells emerge in this phase. They are arranged in a single } \\
\text { layer of pavement cells, which envelop the oocyte. These cells remain in the ovary until the end of the oogenesis } \\
\text { process. }\end{array}$ \\
\hline $\begin{array}{l}\text { Phase III } \\
\text { (Fig. 3c) }\end{array}$ & $\begin{array}{l}\text { The oocyte is larger in relation to the previous phase, and is characterized by the loss of cytoplasmic basophilia } \\
\text { and the start of the formation of cytoplasmic vesicles, signaling the beginning of vitellogenesis. At the start of } \\
\text { this phase, there are few vesicles and their size is reduced. During development, the vesicles increase in number } \\
\text { and in size. The vitelline membrane appears in this phase. It is an acellular and glycoprotein structure located } \\
\text { between the oocyte membrane and the follicular cell layer. This structure remains until the end of oogenesis and } \\
\text { is liberated together with the oocyte during spawning. }\end{array}$ \\
\hline $\begin{array}{l}\text { Phase IV } \\
\text { (Fig. 3d) }\end{array}$ & $\begin{array}{l}\text { The oocyte is larger than in Phase III and two types of cytoplasmic inclusions occur in the cytoplasm: } \\
\text { cytoplasmic vesicles and vitelline granules. The cytoplasmic vesicles migrate to the periphery and the quantity } \\
\text { of vitelline granules increases during development. }\end{array}$ \\
\hline $\begin{array}{l}\text { Phase V } \\
\text { (Fig. 3d) }\end{array}$ & $\begin{array}{l}\text { There is an increase in the oocyte in relation to the previous phase. The vitelline granules occupy practically the } \\
\text { entire area in the oocyte cytoplasm, with the presence of few cytoplasmic vesicles. }\end{array}$ \\
\hline Atretic and/or empty follicles were not considered ovarian follicle development phases because they consist of structures derived from the oogenesis \\
process (Fig. 3e, f, g, h and i).
\end{tabular}

had presented significant correlations with the GSI. The condition factor $(\mathrm{K})$ of both sexes was independent of the abiotic variables used in this work, except the $\mathrm{K}$ of males, which was weakly correlated with water temperature (Table 3 ).

\section{Discussion}

The environmental analysis carried out in the present work, in addition to characterizing the environment, showed the relationship between the temporal variation of the abiotic factors and the gonadal development of E. crossotus.

The influence of environmental variables on gonadal maturation, in the period of spawning and in the distribution pattern of different species of flatfishes, was related by Lange \& Greve (1997), who studied the effect that water temperature has on the reproduction of the species. However, in the present work, gonadal development was not correlated with water temperature, but with rainfall, salinity, and mainly, photoperiod. This is probably associated with the biological clock of the species, which adapt their physiological functions to variations in different environmental factors, depending on the climatic region where they are found. The environmental trigger that sets in motion physiological mechanisms that stimulate the gonadal development of $E$. crossotus seems to be connected to a set of variables, although photoperiod is the most preponderant.

Etropus crossotus is widely distributed in the Atlantic from Chesapeake Bay (USA) to southern Brazil (Rio Grande do Sul State) (Figueiredo \& Menezes, 2000), occurring in both tropical regions and subtropical and temperate regions. Thus,

Table 2. Microscopic description of the main characteristics that determine the ovarian development stages of Etropus crossotus, obtained in the shallow infralittoral areas of the Paranaguá Estuarine Complex.

\begin{tabular}{ll}
\hline Development stages & Microscopic characteristics \\
$\begin{array}{l}\text { Immature (A) } \\
\text { (Fig. 3-a and b) }\end{array}$ & $\begin{array}{l}\text { Found only in young females that never participated in a reproductive cycle. The immature ovaries are characterized by } \\
\text { well-organized ovigerous lamellae, containing oogonia (phase I) and ovarian follicles in phase II. This stage does not } \\
\text { present follicles in vitellogenesis; therefore, the histological cut, when submitted to HE dying, is basophilic. }\end{array}$ \\
\hline $\begin{array}{l}\text { Maturation (B) } \\
\text { (Fig. 3-c) }\end{array}$ & $\begin{array}{l}\text { Characterized by previtellogenic ovarian follicles (phases I and II) and vitellogenic ones (phases III, IV and V). The start } \\
\text { of maturation is marked by the presence of ovarian follicles in phases II and III, and possibly follicles in phase IV (smaller } \\
\text { quantity). In the course of development there is an increase in the quantity of ovarian follicles in phase IV, with the } \\
\text { presence of some follicles in phase V. Thus, when submitted to HE dying, the ovary becomes more eosynophilic. }\end{array}$ \\
\hline $\begin{array}{l}\text { Mature (C) } \\
\text { (Fig. 3-d) }\end{array}$ & $\begin{array}{l}\text { Presents a predominance of ovarian follicles in phase V, together with a smaller quantity of follicles in phase II, and } \\
\text { possibly ovarian follicles in phase IV. Follicles in phase VI may be observed just before spawning. }\end{array}$ \\
\hline $\begin{array}{l}\text { Partially spawned (PS) } \\
\text { (Fig. 3-e, f and g) }\end{array}$ & $\begin{array}{l}\text { This stage occurs only in fishes that present ovarian follicles partially spawned, and is characterized microscopically by } \\
\text { ovarian follicle lots in different development phases (phases II, III, IV and V), together with empty follicles. The presence } \\
\text { of empty follicles indicates the occurrence of spawning of ovarian follicles that have reached the maximum degree of } \\
\text { follicular development. }\end{array}$ \\
\hline $\begin{array}{l}\text { Spawned (D) } \\
\text { (Fig. 3-h and i) }\end{array}$ & $\begin{array}{l}\text { Spawned ovaries end the reproductive period, and are characterized microscopically by oogonia and follicles in phase II } \\
\text { and empty follicles. Initially, the ovigerous lamellae have a disorganized aspect, with a lot of connective tissue between } \\
\text { the follicles and evident vascularization. Later, the ovary goes through a recuperation phase, where the lamellae reorganize } \\
\text { to begin another reproductive cycle. }\end{array}$ \\
\hline
\end{tabular}




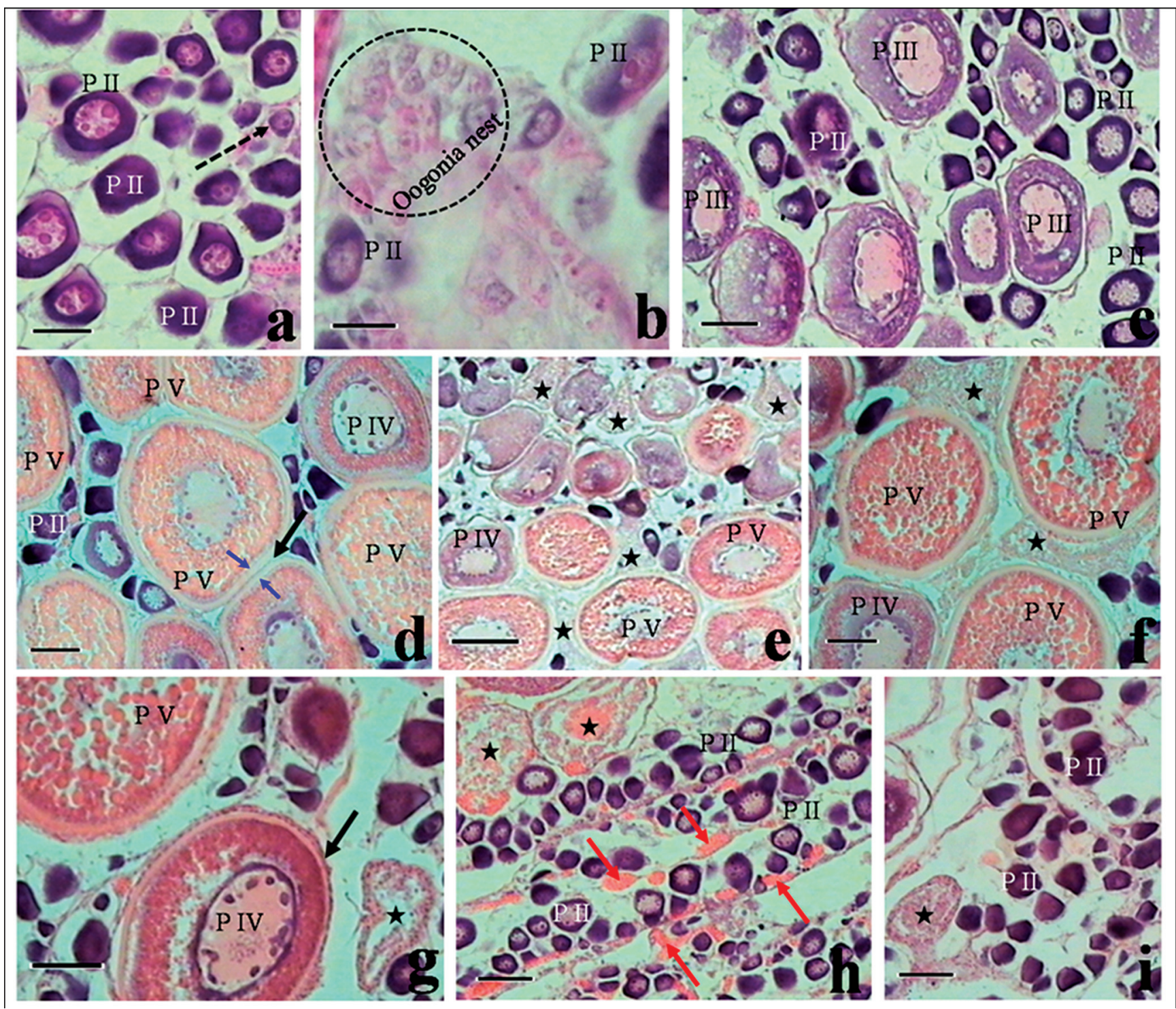

Fig. 3. Histology cuts of Etropus crossotus ovaries, stained with HE. a - Immature ovary containing ovarian follicles in phases I (arrow) and II (P II) (scale: $40 \mu \mathrm{m}$ ); b - Immature ovary, in detail, containing an "oogonia nest" (circle) + follicles in phase II (scale: $20 \mu \mathrm{m}$ ); $\mathbf{c}$ - Maturing ovary containing follicles in phases II and III (P III) (scale: $80 \mu \mathrm{m}$ ); d - Mature ovary containing follicles in phases II, IV (P IV) and, predominantly, V (PV). The blue arrows point to the vitelline membrane and the black arrow indicates the zone of contact between the follicular cells of two follicles in phase V, separated by scarce connective tissue (scale: $80 \mu \mathrm{m}$ ); $\mathbf{e}$ Partially spawned ovary (panoramic view) containing follicles in phases II, IV and V + empty follicles (asterisk) (scale: $190 \mu \mathrm{m}$ ); f - Partially spawned ovary containing ovarian follicles in phases IV and V + empty follicles (asterisk) (scale: $80 \mu \mathrm{m}$ ); $\mathbf{g}$ - Partially spawned ovary (in detail) containing follicles in phases IV and V + empty follicles (asterisk). The arrow points to follicular cells (scale: $80 \mu \mathrm{m}$ ); h - Spawned ovary containing cells in phase II + empty follicles (asterisk) + high degree of vascularization (scale: $80 \mu \mathrm{m}) ; \mathbf{i}$ - Spawned ovary (in detail) containing follicles in phase II + empty follicles (asterisk) (scale: $80 \mu \mathrm{m}$ ).

this species probably does not have the same reproductive period in every region, or the same reproductive tactics.

The period of highest reproductive activity of $E$. crossotus occurred from October to January (spring to the beginning of summer), corroborating Dando (1984). This author reports that the period of highest gonadal development of most subtropical estuarine fish species is spring, due to the greater survival probability of the offspring in the subsequent seasons, when there is a greater availability of resources. These presumptions are corroborated by Chaves (1994), Chaves (1995), Chaves \& Vendel (1997), Rocha et al. (2002), Schultz et al. (2002), Favaro et al. (2003), Favaro et al. (2005) and Favaro et al. (2007), who reported spring to be the period of highest reproductive activity for different residentestuarine species of the Paraná state coast (subtropical region of Brazil). However, different results were recorded by 


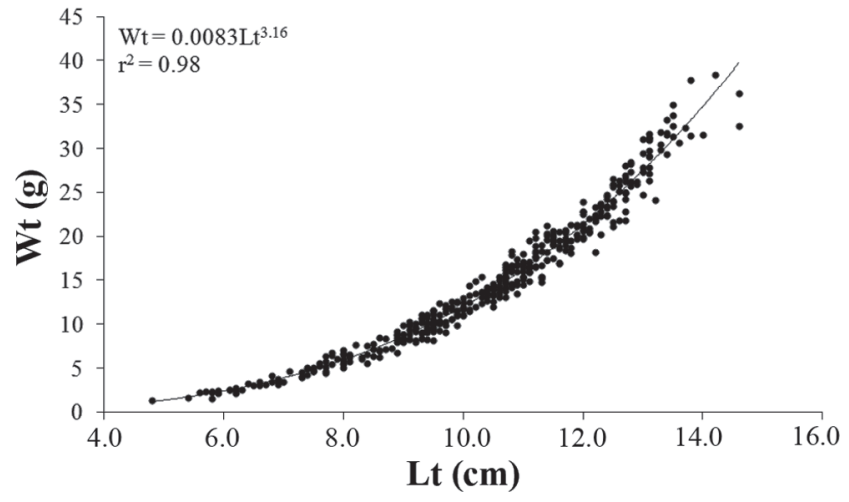

Fig. 4. Weight-length relationship for grouped sexes of Etropus crossotus in the shallow infralittoral areas of the Paranaguá Estuarine Complex. Total amostral $N=395$, female $\operatorname{amostral} N=171$, and male amostral $N=224$.
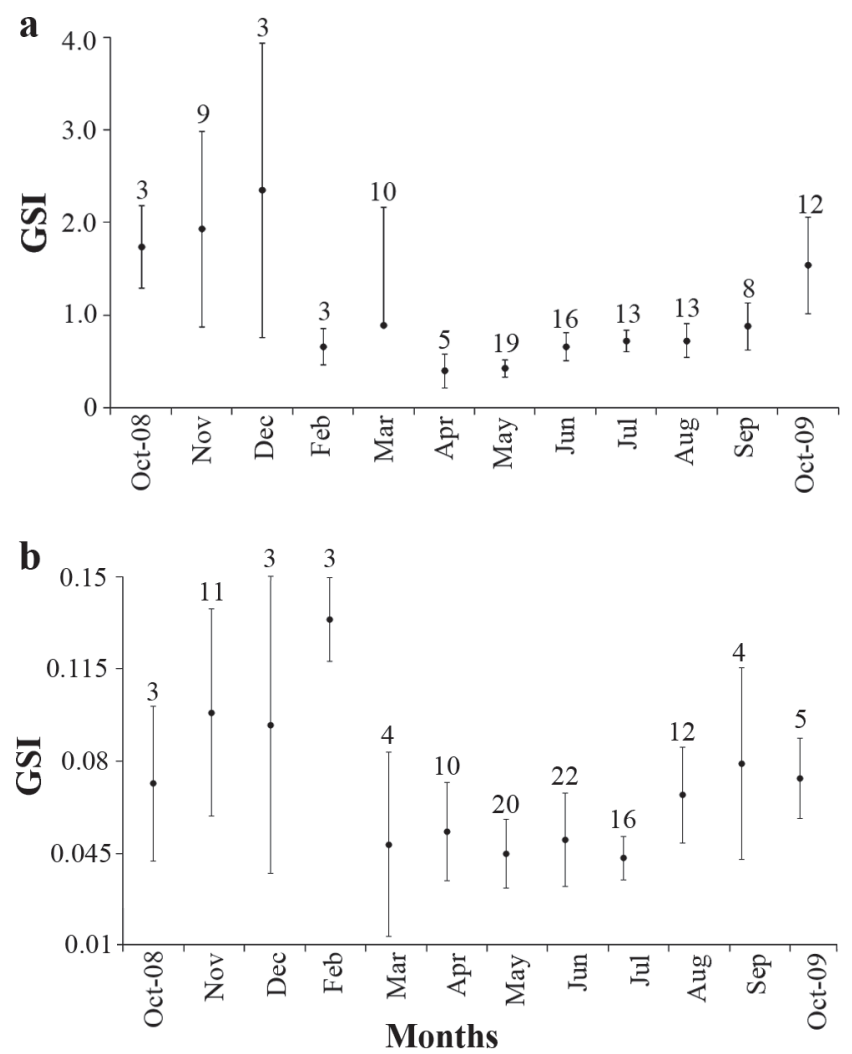

Fig. 5. Monthly variation of the mean GSI of females (a) and males (b) of Etropus crossotus in the shallow infralittoral areas of the Paranaguá Estuarine Complex. GSI = gonadosomatic index. The error bars correspond to the standard deviation. The numbers indicated above the error bars refer to absolute frequency.

researchers that work with estuarine species in the tropical region of Brazil (Barbieri et al., 1991; Gomes et al., 1999; Pessanha \& Araujo, 2001). According to Lowe-McConnell (1999), and corroborating the presumptions above, the reproduction period occurs at different times along the

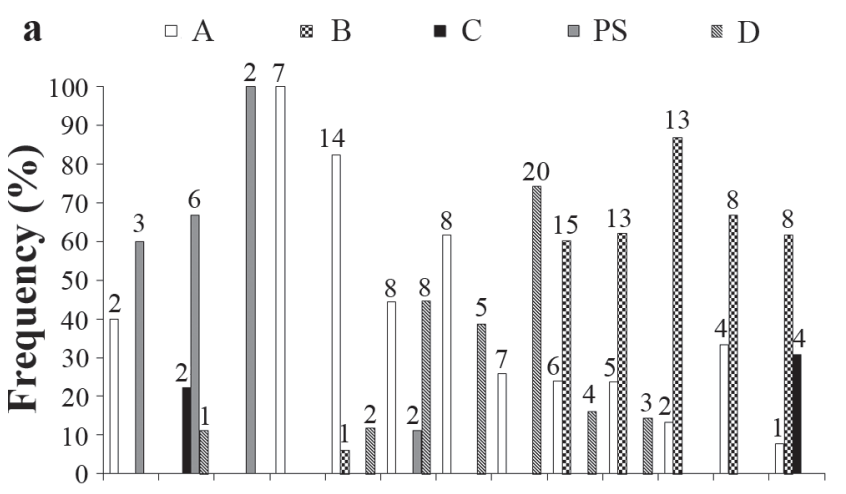

b

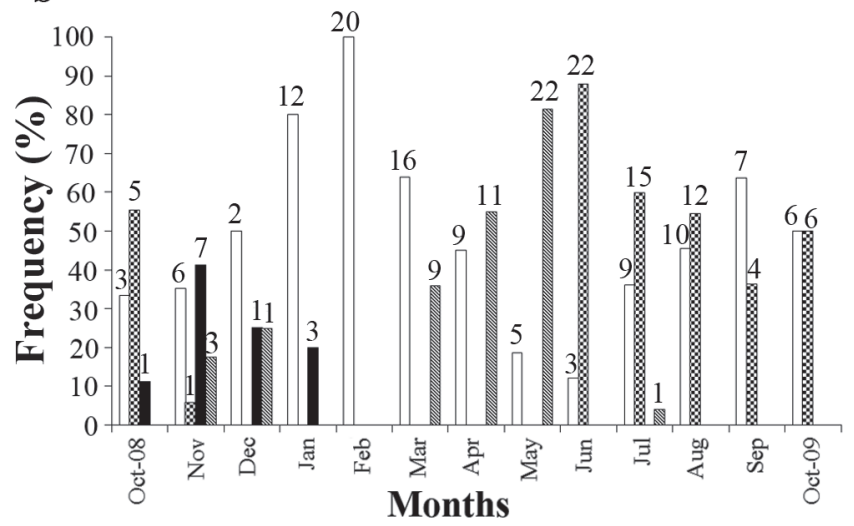

Fig. 6. Monthly percentage frequency distribution of the gonadal maturation stages of females (a) and males (b) of Etropus crossotus in the shallow infralittoral areas of the Paranaguá Estuarine Complex. $\mathrm{A}=$ immature; $\mathrm{B}=$ maturation; $\mathrm{C}$ $=$ mature $; \mathrm{PS}=$ partially spawned $; \mathrm{D}=$ spawned/emptied. The numbers indicated above the bars refer to absolute frequency.

Brazilian coast, probably due to differences in the prevailing environmental conditions (abiotic: temperature and photoperiod; biotic: availability of adequate food during the first phases of development).

In this study the development of the ovarian follicles of E. crossotus followed the same basic pattern described for other teleosts. According to Tyler \& Sumpter (1996) and Brooks et al. (1997), oocytes of teleosts present the same growth pattern; however, their strategies and reproductive tactics vary widely. As regards ovarian follicle development, estuarine and/or marine fishes (e.g. E. crossotus) have one more phase than freshwater fishes (Vazzoler, 1996). This difference in the number of oocyte development phases is due to pre-ovulatory hydration, which is observed only in marine and estuarine fishes, where there is coalescence of vitelline granules and substantial increase in volume. According to Chaves (1989), this characteristic was acquired through an environmental adaptive convergence.

Etropus crossotus females with follicles in pre-ovulatory hydration were not caught in the present study, even knowing that species that spawn in estuarine and/or marine environments must be in this condition. According to Patiño \& 

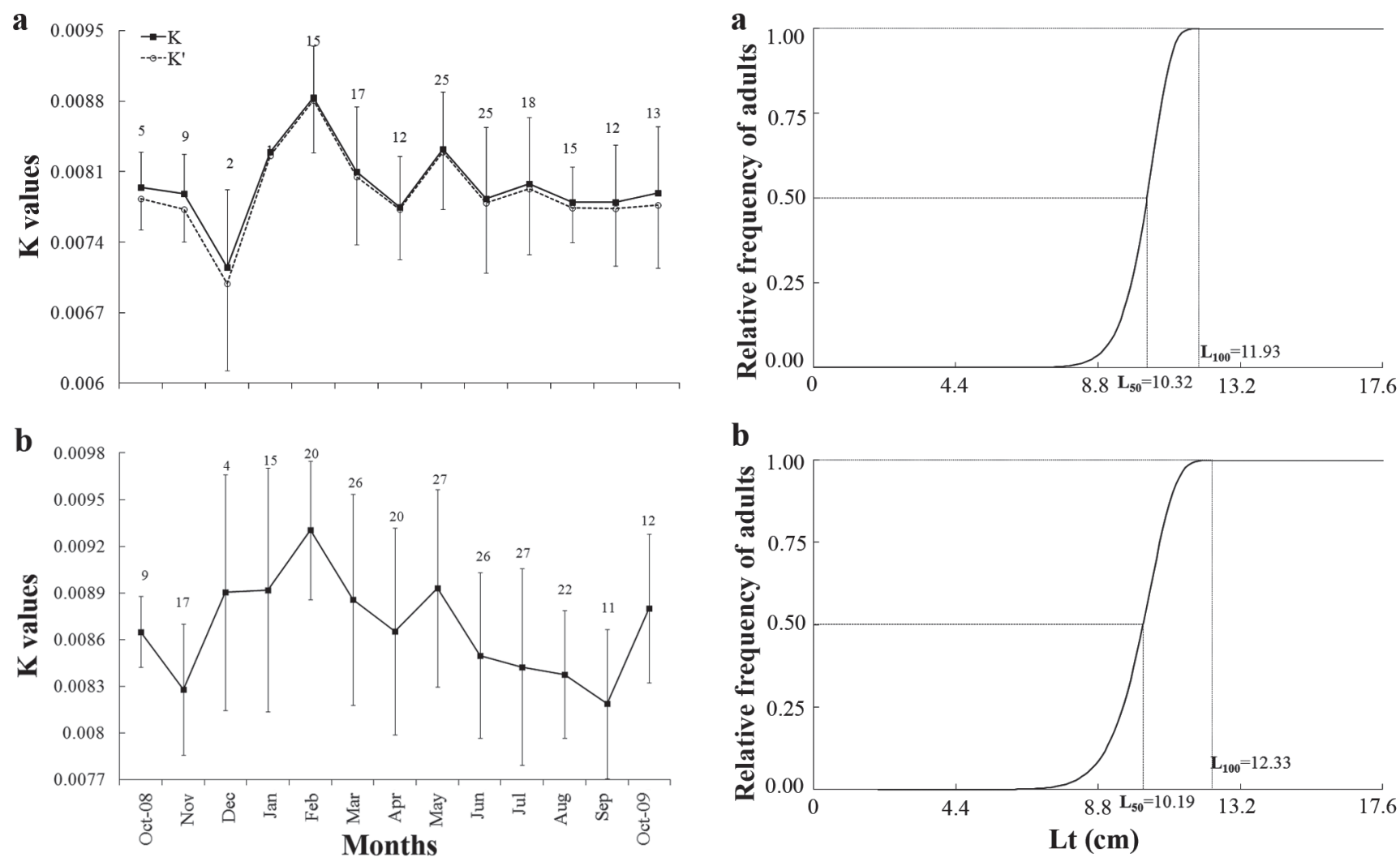

b

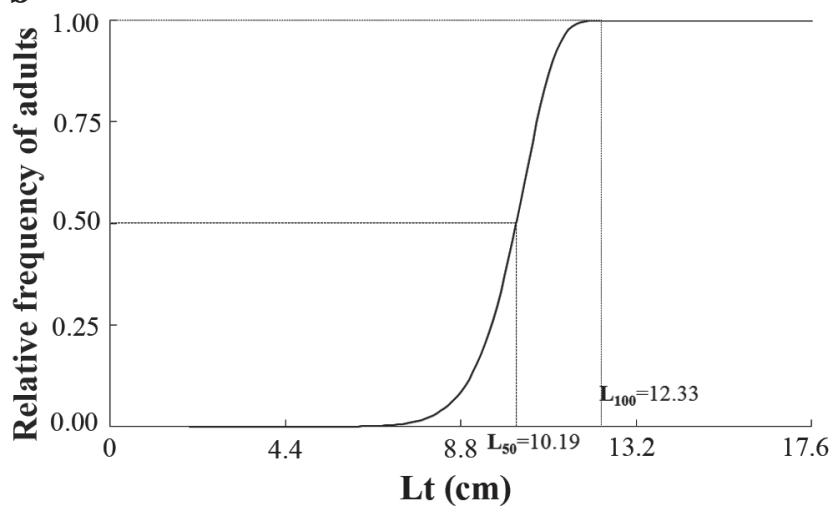

Fig. 7. Monthly mean value of the total condition factor $(\mathrm{K})$ and the somatic condition factor $\left(\mathrm{K}^{\prime}\right)$ of females (a) and the total condition factor of males (b) of Etropus crossotus in the shallow infralittoral areas of the Paranaguá Estuarine Complex. The error bars correspond to the standard deviation. The numbers indicated above the error bars refer to absolute frequency.

Sullivan (2002), the process of hyalinization of the oocytes occurs only moments before their release into the environment.

The results found for both sexes of E. crossotus, with the obtainment of individuals with mature, spawned/spermiated and immature gonads, consistently support the assertion that the species uses the study area for reproduction and recruitment. In addition, the capture of $E$. crossotus individuals during the entire study period and in every gonadal development stage allows this species to be classified as resident-estuarine. According to Blaber (2002), a residentestuarine species is one which completes its entire life cycle in estuaries. However, species classified as resident-estuarine may make use of marine areas at certain times of the year to forage, if they can tolerate the marine characteristics. This was observed by Lunardon-Branco \& Branco (2003), who studies the diet of E. crossotus in marine areas adjacent to an estuarine area on the coast of Santa Catarina State (subtropical region of Brazil).

The occurrence of partially spawned females demonstrates that the species presents multiple pawning with synchronous ovarian development in more than one lot. This type of ovarian development is reported by Wooton (1998)

Fig. 8. First maturation length for females (a) and males (b) of Etropus crossotus in the shallow infralittoral areas of the Paranaguá Estuarine Complex. $\mathrm{L}_{50}=$ the shortest total length (Lt), in which $50 \%$ of the individuals sampled were adults. $\mathrm{L}_{100}=$ the shortest total length (Lt), in which $100 \%$ of the individuals sampled were adults. Female amostral $\mathrm{N}=171$, and male amostral $\mathrm{N}=218$.

as common in environments where great fluctuations occur (e.g. estuaries) (Kupschus \& Tremain, 2001).

The information described above shows the importance of the use of histological analysis in fish reproduction studies, since it allows better understanding of the dynamics in the development of germ cells, showing the subtle details of the oogenesis process. According to West (1990), histological studies furnish precise information about the development stage of the oocyte, and according to Chaves (1989) and Dias et al. (1998), only macroscopic analysis of the gonads leads to erroneous results in the determination of the gonadal development stages. Veregue \& Orsi (2003) reported that the correct identification of the gonadal development stages, sex ratio, and ratio of young and adult individuals is fundamental to understanding the use a certain species makes of an area or system.

The variations found in $\mathrm{K}$ and $\mathrm{K}$ ' also reflect the reproductive process. During the months before the reproductive period, there is an accumulation of tissue necessary to endure the reproductive cycle (Abelha \& Goulart, 2008). The allocation of energetic resources to the 

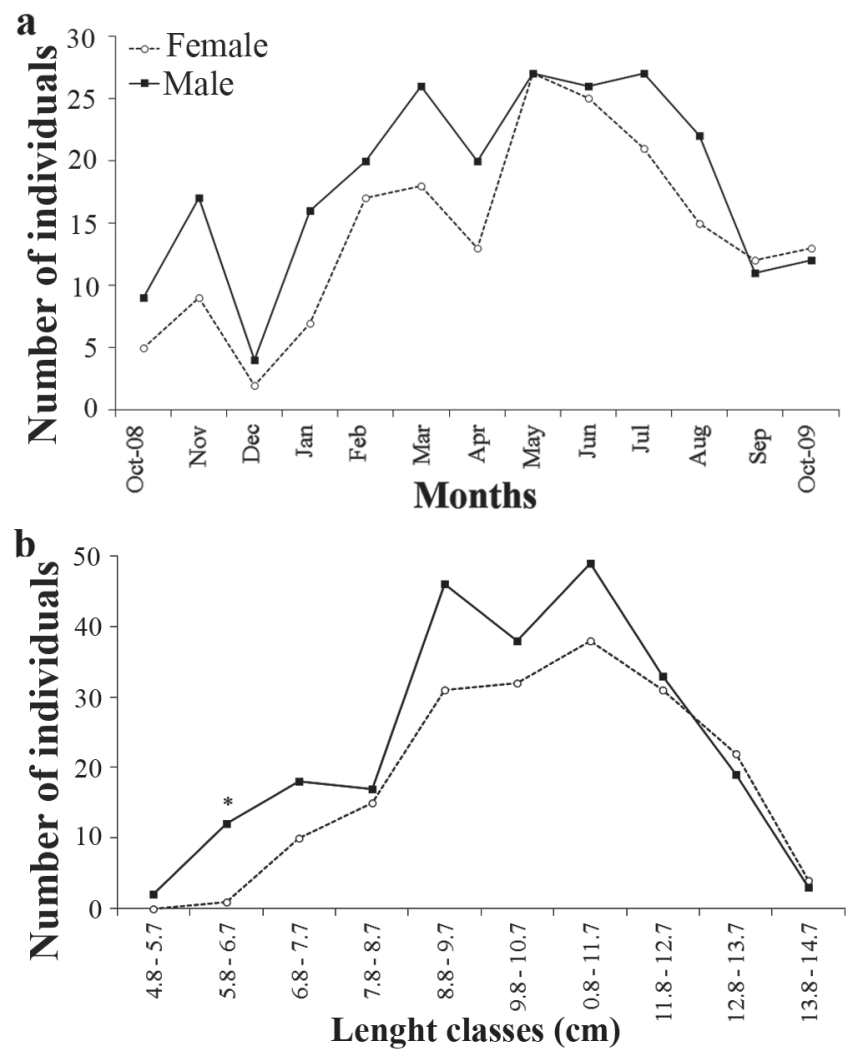

Fig. 9. Monthly sex ratio (a) per length class (b) of Etropus crossotus in the shallow infralittoral areas of the Paranaguá Estuarine Complex. (a) Female amostral $\mathrm{N}=184$, and male amostral $\mathrm{N}=237$; (b) Female amostral $\mathrm{N}=184$, male amostral $\mathrm{N}=237$, and unsexed amostral $\mathrm{N}=5$. *Significant values $(\mathrm{p}<$ 0.05 ) for chi-square test.

gonads during the reproductive period and the stress caused by spawning/spermiation decrease the nutritive condition of the individuals. On the other hand, in the post-spawning/ spermiation period (summer), when there is a greater availability of resources (Lowe-McConnell, 1999), there is a substantial increase in the well-being of the individuals.

The verification that the recruitment period is in January, February and March corroborates Dando (1984), who reported an increase in the catches of young estuarine fishes during the summer. According to Jobling (1995) and Lowe-McConnell (1999), the greatest availability of food adequate for the first phases of development of the juveniles during the summer (highest temperatures) is a determining factor for the recruitment period of ichthyic species in temperate and subtropical regions.

The weight-length relationship and the size of the individuals for most fish species is, generally, one of the more frequent forms of sexual dimorphism (Nikolsky, 1963). In the present work both sexes presented positive allometric growth, with no differences between them. A different outcome was described for the flatfish species Achirus lineatus, from the Paranaguá Estuarine Complex, where

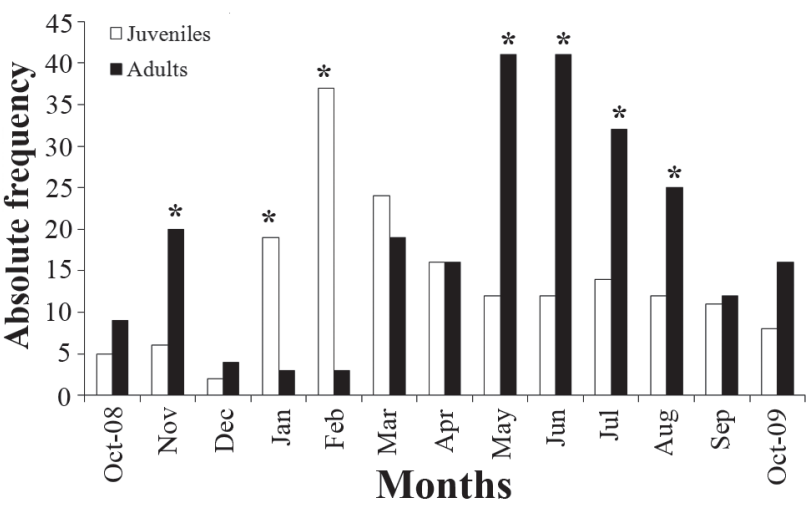

Fig. 10. Monthly absolute frequency distribution of juveniles and adult individuals of Etropus crossotus in the shallow infralittoral areas of the Paranaguá Estuarine Complex. Total amostral $\mathrm{N}=419$. *Significant values $(\mathrm{p}<$ 0.05 ) for chi-square test.

allometric growth was negative for females and positive for males (Oliveira \& Fávaro, 2010).

The sex ratio of $E$. crossotus did not present significant difference between the sexes over the entire study period. This pattern was different from the ones that were found for most of the resident-estuarine fish species studied in the Paranaguá Estuarine Complex (Paraná State). The works carried out by Favaro et al. (2007), with the silverside Atherinella brasiliensis, and Oliveira \& Favaro (2010), with the flatfish Achirus lineatus, were two of the works that corroborated the prediction above.

The verification of the same ratio between the sexes, when they were distributed in length classes, shows that the E. crossotus individuals present similar sizes, independent of sex. This is not a common pattern in fish studies, since, generally, body size in females is favored by the increase in fecundity; whereas in males, size is affected by sexual selection (Shine, 1990).

In conclusion, the species $E$. crossotus can be considered resident-estuarine because it completes its entire life cycle in this environment and depends on the conservation of these areas to maintain its stocks. Its reproductive cycle is well-synchronized to the temporal variations implicit in subtropical regions. Partial spawning, weight-length

Table 3. Result of the Spearman correlation $\left(R_{S}\right)$ between the analyzed environmental factors and the reproductive indices of females and males of E. crossotus in the shallow infralittoral areas of the Paranaguá Estuarine Complex. GSI = gonadosomatic index. $\mathrm{K}=$ total condition factor. *Significant values $(\mathrm{p}<0.05)$.

\begin{tabular}{lcccc}
\hline \multirow{2}{*}{ Factors } & \multicolumn{2}{c}{$\mathrm{R}_{\mathrm{s}}$ females } & \multicolumn{2}{c}{$\mathrm{R}_{\mathrm{s}}$ males } \\
\cline { 2 - 5 } & $\mathrm{GSI}$ & $\mathrm{K}$ & $\mathrm{GSI}$ & $\mathrm{K}$ \\
\hline Water temperature $\left({ }^{\circ} \mathrm{C}\right)$ & -0.15 & 0.07 & 0.13 & $0.23^{*}$ \\
Photoperiod $(\mathrm{h})$ & $0.55^{*}$ & -0.13 & $0.60^{*}$ & -0.10 \\
Accumulated precipitation $(\mathrm{mm})$ & $0.42^{*}$ & 0.01 & $0.45^{*}$ & 0.06 \\
Salinity $(\%)$ & $-0.41 *$ & 0.10 & $-0.52^{*}$ & 0.03 \\
\hline
\end{tabular}


relationship and sex ratio were considered reproductive tactics of the species and used to obtain greater reproductive success in the study area. The first maturation length determined in this study helps in the implementation of laws that regulate fishery activity, aquaculture and the management (when necessary) of estuarine regions.

\section{Acknowledgements}

The authors thank the Coordenação de Aperfeiçoamento de Pessoal de Nível Superior (CAPES) for the concession of scholarship.

\section{Literature Cited}

Abelha, M. C. F. \& E. Goulart. 2008. Population structure, condition factor and reproductive period of Astyanax paranae (Eigenmann, 1914) (Osteichthyes: Characidae) in a small and old brazilian reservoir. Brazilian Archives of Biology and Technology, 51: 503-512.

Andriguetto-Filho, J. M., P. T. C. Chaves, C. Santos \& S. A. Liberati. 2006. Diagnóstico da Pesca no estado do Paraná. In: Issac, V. J., M. A. Martins, M. Haimovici \& J. M. Andriguetto-Filho (Eds.). Pesca marinha e estuarina do Brasil no início do século XXI: Recursos, tecnologias, aspectos socioeconômicos e institucionais. Editora Universitária UFPA, Belém do Pará, 188p.

Bailey, K. M., A. A. Abookire \& J. T. Duffy-Anderson. 2008. OCEAN transport paths for the early life history stages of offshore-spawning flatfishes: a case study in the Gulf of Alaska. Fish and Fisheries, 9: 44-66.

Barbieri, L. R. R., J. V. Andreata, M. A. Santos, M. H. C. Silva, A. S. C. Sebilia \& R. P. Santos. 1991. Distribuição e ciclo de vida das espécies de peixes mais abundantes da Laguna de Marapendi, Rio de Janeiro, Brasil. Revista Brasileira de Zoologia, 7: 223-243.

Berendzen, P. B. \& W. W. Dimmick. 2002. Phylogenetic relationships of Pleuronectiformes based on molecular evidence. Copeia, 2002: 642-652.

Blaber, S. J. M. 2002. 'Fish in hot water': the challenges facing fish and fisheries research in tropical estuaries. Journal of Fish Biology, 61: 1-20.

Brooks, S., C. R. Tyler \& J. P. Sumpter. 1997. Egg quality in fish: what makes a good egg? Reviews in Fish Biology and Fisheries, 7: 387-416.

Chaves, P. T. C. 1989. Hidratação pré-ovulatória em peixes: um caráter de origem marinha? Revista Brasileira de Zoologia, 6: 463-472.

Chaves, P. T. C. 1994. A incubação de ovos e larvas em Genidens genidens (Valenciennes) (Siluriformes, Ariidae) da Baía de Guaratuba, Paraná, Brasil. Revista Brasileira de Zoologia, 11: 641-648.

Chaves, P. T. C. 1995. Atividade reprodutiva de Bardiella ronchus (Curvier) (Peixes, Sciaenidae) na Baía de Guaratuba, Paraná. Revista Brasileira de Zoologia, 12: 759-766.

Chaves, P. T. C. \& A. Serenato. 1998. Diversidade de dietas na assembléia de linguados (Teleostei, Pleuronectiformes) do manguezal da Baía de Guaratuba, Paraná, Brasil. Revista Brasileira de Oceanografia, São Paulo, 46: 61-68.

Chaves, P. T. C. \& A. V. Vendel. 1997. A reprodução de Stellifer rastrifer (Jordan) (Teleostei, Sciaenidae) na Baía de Guaratuba, Paraná, Brasil. Revista Brasileira de Zoologia, 14: 81-89.
Dando, P. R. 1984. Reproduction in Estuarine Fish. Pp. 155-170. In: Potts, G. W. \& R. J. Wootton (Eds.). Fish Reproduction: Strategies and Tactics. San Diego, Academic Press, 424p.

Dias, J. F., C. B. Fiadi, H. L. N. Silbiger \& L. S. H. Soares. 2005. Reproductive and population dynamics of the Bay whiff Citharichthys spilopterus Günther, 1862 (Pleuronectiformes: Paralychthyidae) in the Mamanguá Inlet, Rio de Janeiro, Brazil. Neotropical Ichthyology, 3: 411-419.

Dias, J. F., E. Peres-Rio, P. T. C. Chaves \& C. L. D. B. RossiWongtschowski. 1998. Análise Macroscópica dos Ovários de Teleósteos: Problemas de Classificação e Recomendações de Procedimentos. Revista Brasileira de Biologia, 58: 55-69.

Fávaro, L. F., F. A. Frehse, R. N. Oliveira \& R. Schwarz. 2005. Reprodução do bagre amarelo, Cathorops spixii (Agassiz) (Siluriformes, Ariidae), da Baía de Pinheiros, região estuarina do litoral do Paraná, Brasil. Revista Brasileira de Biologia, 22: 1022-1029.

Fávaro, L. F., S. C. G. Lopes \& H. L. Spach. 2003. Reprodução do peixe-rei, Atherinella brasiliensis (Quoy \& Gaimard) (Atheriniformes, Atherinidae), em uma planície de maré adjacente à gamboa do Baguaçu, Baía de Paranaguá, Paraná, Brasil. Revista Brasileira de Zoologia, 20: 501-506.

Fávaro, L. F. \& E. C. Oliveira. 2011. Ecologia Reprodutiva em Peixes. In: Ribeiro, C. A. O. (Ed.). Técnicas em histologia. Santos, Editora Santos, 422p.

Fávaro, L. F., E. C. Oliveira \& N. F. Verani. 2007. Estrutura da população e aspectos reprodutivos do peixe-rei Atherinella brasiliensis (Quoy \& Gaimard) (Atheriniformes, Atherinopsidae) em áreas rasas do complexo estuarino de Paranaguá, Paraná, Brasil. Revista Brasileira de Zoologia, 24: 1150-1156.

Félix, F. C., H. L. Spach, P. S. Moro, C. W. Hackradt, G. M. L. N. Queiroz \& M. Hostim-Silva. 2007. Ichthyofauna composition across a wave - energy gradient on southern brazil beaches. Brazilian Journal of Oceanography, 55: 281-292.

Figueiredo, J. L. \& N. Menezes. 2000. Manual de Peixes Marinhos do Sudeste do Brasil - VI. Teleostei (5). São Paulo, Editora da Universidade de São Paulo, 116p.

Gomes, I. D. \& F. G. Araujo. 2004. Reproductive biology of two marine catfishes (Siluriformes, Ariidae) in the Sepetiba Bay, Brazil. Revista de Biologia Tropical, 52: 143-156.

Gomes, L. D., F. G. Araújo, M. C. C. Azevedo \& A. L. M. Pessanha. 1999. Biologia reprodutiva dos bagres marinhos, Genidens genidens (Valencianes) e Cathorops spixii (Agassiz) (Siluriformes, Ariidae) na Baía de Sepetiba, Rio de Janeiro, Brasil. Revista Brasileira de Zoologia, 16: 171-180.

Guedes, A. P. P. \& F. G. Araujo. 2008. Trophic resource partitioning among five flatfish species (Actinopterygii, Pleuronectiformes) in a tropical bay in south-eastern Brazil. Journal of Fish Biology, 72: 1035-1054.

Guedes, A. P. P., F. G. Araujo \& M. C. C. Azevedo. 2004. Estratégia trófica dos linguados (Quoy \& Gaimard) (Actinopterygii, Pleuronectiformes) na Baía de Sepetiba, Rio de Janeiro, Brasil. Revista Brasileira de Zoologia, 21: 857-864.

Instituto Paranaense de Desenvolvimento Econômico e Social (Ipardes). 2001. Zoneamento da Área de Proteção Ambiental de Guaraqueçaba. Curitiba, Ipardes, 150p.

Jobling, M. 1995. Environmental Biology of Fishes. London, Chapman \& Hall, 455p.

Kupschus, S. \& D. Tremain. 2001. Associations between fish assemblages and environmental factors in nearshore habitats of a subtropical estuary. Journal of Fish Biology, 58: 1383-1403. 
Lamour, M. R. 2007. Morfodinâmica Sedimentar da Desembocadura do Complexo Estuarino de Paranaguá -PR. Unpublished Ph.D. Dissertation, Universidade Federal do Paraná, Curitiba,161p.

Lamour, M. R., C. R. Soares \& J. C. Carrilho. 2004. Mapas de parâmetros texturais de sedimentos de fundo do complexo estuarino de Paranaguá-PR. Boletim Paranaense de Geociências, 55: 77-82.

Lana, P. C., E. Marone, R. M. Lopes, E. Machado. 2001. The subtropical estuarine complex of Paranaguá Bay, Brazil. Pp. 131-145. In: Seeliger, U. \& B. Kjerfre (Eds.). Coastal marine ecosystems of Latin America. Berlim, Springer, 360p.

Lange, U. \& W. Greve. 1997. Does temperature influence the spawning time, recruitment and distribution of flatfish via its influence on the rate of gonadal maturation? German Journal of Hydrography, 49: 251-263.

Lowe-McConnell, R. H. 1999. Estudos Ecológicos de Comunidades de Peixes Tropicais. São Paulo, Editora da Universidade de São Paulo, 535p.

Lunardon-Branco, M. J. \& J. O. Branco. 2003. Alimentação natural de Etropus crossotus Jordan \& Gilbert (Teleostei, Pleuronectiformes, Paralichthyidae), na Armação do Itapocoroy, Penha, Santa Catarina, Brasil. Revista Brasileira de Zoologia, 20: 631-635.

Mendonça, P. \& F. G. Araujo. 2002. Composição das populações de linguados (Osteichthyes, Pleronectiformes) da Baía de Sepetiba, Rio de Janeiro, Brasil. Revista Brasileira de Zoologia, 19: 339-347.

Nelson, J. S. 2006. Fishes of the World. New York, WileyInterscience, $4^{\mathrm{a}}$ ed., $624 \mathrm{p}$.

Nikolsky, G. V. 1963. The ecology of fishes. London, Academic Press, 351p.

Oliveira, E. C. \& L. F. Fávaro. 2010. Reproduction of the flatfish Achirus lineatus (Pleuronectiformes, Achiridae) in Paranaguá Bay-PR, a subtropical region in Brazil. Zoologia, 27: 523-532.

Pardo, B. G., A. Machordom, F. Foresti, F. Porto-Foresti, M. F. C. Azevedo, R. Boñón, L. Sanches \& P. Martinez. 2005. Philogenetic analysis of flatfish (Order Pleuronectiformes) based on mitochondrial 16s rDNA sequences. Scientia Marina, 69: 531-543.

Patiño, R. \& C. V. Sullivan. 2002. Ovarian follicle growth, maturation, and ovulation in teleost fish. Fish Physiology and Biochemistry, 26: 57-70.

Pessanha, A. L. M. \& F. G. Araújo. 2001. Recrutamento do peixe-rei, Atherinella brasiliensis (Quoy \& Gaimard) (Atheriniformes, Atherinopsidae), na margem continental da baía de Sepetiba, Rio de Janeiro, Brasil. Revista Brasileira de Zoologia, 18: 1265-1274.
Queiroz, G. M. N., H. L. Spach, M. Sobolewski-Morelos, L. O. Santos \& R. Schwarz. 2006. Caracterização da ictiofauna demersal de duas áreas do complexo estuarino de Paranaguá, Paraná, Brasil. Biociências, 14: 112-124.

Rocha, C., L. F. Favaro \& H. L. Spach. 2002. Biologia reprodutiva de Sphoeroides testudineus (Linnaeus) (Pisces, Osteichthyes, Tetraodontidae) da gamboa do Baguaçu, Baía de Paranaguá, Paraná, Brasil. Revista Brasileira de Zoologia, 19: 57-63.

Schultz, Y. D., L. F. Favaro, \& H. L. Spach. 2002. Aspectos reprodutivos de Sphoeroides greeleyi (Gilbert) (Pisces, Osteichthyes, Tetraodontidae), da gamboa do Baguaçu, Baía de Paranaguá, Paraná, Brasil. Revista Brasileira de Zoologia, 19: 65-76.

Shine, R. 1990. Proximate determinants of sexual differences in body size. American Naturalist, 135: 278-283.

Shiota, T., A. Ishimatsu \& K. Soyano. 2003. Effects of temperature on gonadal development of mudskipper (Periophthalmus modestus). Fish Physiology and Biochemistry, Holanda, 28: 445-446.

Sokal, R. R. \& F. J. Rohlf. 1981. Biometry. New York, W. H. Freeman, 859p.

Takeuti, D. F., J. R. Verani, J. M. R. Aranha \& M. S. Menezes. 1999. Population structure and condition factor of Pseudotothyris obtusa (Loricariidae, Hypoptopomatinae), from three coastal streams in Southern Brazil. Brazilian Archives of Biology and Technology, 42: 397-403.

Tyler, C. R. \& J. P. Sumpter. 1996. Oocyte growth and development in teleosts. Reviews in Fish Biology and Fisheries, 6: 287-318.

Vazzoler, A. E. M. 1996. Biologia da reprodução de peixes teleósteos: teoria e prática. Maringá, EDUEM, 169p.

Veregue, A. M. L. \& M. L. Orsi. 2003. Biologia reprodutiva de Astyanax scabripinnis paranae (Eingenmann) (Ostheichthyes, Characidae), do ribeirão das Marrecas, bacia do rio Tibagi, Paraná. Revista Brasileira de Zoologia, 20: 97-105.

Vitule, J. R. S; M. R. Braga \& J. M. R. Aranha. 2008. Population structure and reproduction of Deuterodon langei Travassos, 1957 (Teleostei, Characidae) in a neotropical stream basin from the atlantic forest, southern Brazil. Brazilian Archives of Biology and Technology, 51: 1187-1198.

West, G. 1990. Methods of assessing ovarian development in fishes: a review. Australian Journal of Marine and Freshwater Research, 41: 199-222.

Wooton, J. R. 1998. Ecology of teleost fishes. New York, Kluwer Academic Publishers, $2^{\text {nd }}$ ed., 386p.

Submitted January 12, 2011

Accepted September 6, 2011

Published December 26, 2011 